\title{
Alec Craig, Censorship and the Literary Marketplace: A Bookman's Struggles
}

\author{
Richard Espley
}

Alec Craig (1897-1973) was a passionate and committed campaigner, widely published, and embedded in a diffuse movement of progressive societies for over four decades. Undoubtedly his deepest commitment was his opposition to literary censorship, and he distinguished himself from contemporaries in this debate with a depth of knowledge and suspicion of established, bivalent discourses concerning the obscene and the valuable. Craig is now largely forgotten, often merely a footnote in histories of censorship. To an extent, he foresaw and understood this outcome, suggesting that he made "ever diminishing demands with ever diminishing hope." Craig sought to shape debate by pushing at the extreme edge of demands for reform, pragmatically stating of his arguments that "I am well aware that the suggestions...will satisfy no one." Whatever his achievements, this chapter does not seek primarily to reclaim Craig as a major literary figure, but will explore his writing as a critique of, and a case study in, the convoluted attitudes to the cultural and commercial handling of books. In the process, many of Craig's arguments (as well as his seeming failures) will emerge as prescient pathways to a more informed, less legalistic handling of the culturally uncomfortable.

Craig's first published work was Sex and Revolution (1934), an ambitious attempt to describe and champion what he saw as a fundamental attitudinal change towards sexual morality that he branded "modernist." In many ways a cri de coeur foreshadowing all of his later work, the volume embraced a diverse range of social causes, all united by Craig's perception of the cultural inability to discuss sexuality. For example, it sets forth a programme of reforms including easier divorce, legal abortion, the decriminalisation of homosexuality, the abandonment of legal restrictions on the illegitimate and the promotion of nudism. His idea of the "modernist" is idiosyncratic, but he suggests that such a figure "sees human desire and looks on it with kindly eyes." ${ }^{3}$ Craig's first

1 Alec Craig, The Aspirin Eaters (London: Fortune, 1943), pp. 6-7.

2 Alec Craig, The Banned Books of England and Other Countries: A Study of the Conception of Literary Obscenity (London: Allen \& Unwin, 1962), p. 208.

3 Alec Craig, Sex and Revolution (London: Allen \& Unwin, 1934), p. 62. 
prescription for an ailing society was the abandonment of legal restriction on sexual expression, so that society might rejoice in lovers' "reciprocal fulfilment if this can be brought about without injury to human life." 4 The second recommendation he urged was the education of all men and women in sexual matters. In a culture bristling with pamphleteers and campaigners he found supportive institutions and with one such body, the Federation of Progressive Societies and Individuals, Craig organised a series of lectures for the young. These were held in the London School of Hygiene and Tropical Medicine in 1935, entitled "Elementary Sexology."5 This attempt to rebuild society, one lecture theatre at a time, speaks loudly to Craig's immersion in a moment of utopian social optimism in the decades after the First World War, with his own libertarian instincts arguably shaped by trauma on the Western Front in 1917.

Emerging from this crusade was The Banned Books of England and Other Countries (1937), by far Craig's most influential work, and that which achieved something closest to commercial success. This was a historical survey of, and manifesto against, censorship. As Craig himself pointed out, "there is no literary censorship in England in the true sense of the word," but rather a complex legal agglomeration around the concept of 'libel' which he set out to critique and hopefully dismantle. ${ }^{6}$ Drawing on the Obscene Publications Act of 1857 but also various other legal instruments, the state and its organs could prosecute, destroy or seize books in a perplexing variety of ways, from confiscation and burning by Her Majesty's Customs to summary banning by magistrates. Craig's objections were manifold, but one of the most pressing was "the deprivation which the community suffers" as a result of literary suppression. ${ }^{7}$ As a cause of such suffering, he saw publishers' fear of prosecution as more significant than the direct effect of the law itself: "it must not be thought that the number of prosecutions is a measure of the amount of literary suppression... many books never reach publication for fear of the law." 8

The public debate over censorship, or rather as Craig put it the "conflict between liberal and authoritarian ideas," had not subsided since the prosecution of Radclyffe Hall's The Well of Loneliness in 1928. ${ }^{9}$ As Alan Travis remarks,

4 Ibid., p. 63.

5 See Alec Craig, 'An experiment in adult education,' in John Haden Badley and Mary Ware Dennett, eds., Experiments in Sex Education (London: Federation of Progressive Societies and Individuals, 1935), pp. 39-45.

6 Craig, Banned Books (see above, n. 2), p. 19.

7 Alec Craig, Above All Liberties (London: Allen \& Unwin, 1942), p. 97.

8 Craig, Banned Books (see above, n. 2), p. 43.

9 Ibid., p. 208. 
this trial, initiated by Home Secretary Sir William Joynson-Hicks - "the puritanical purge of publishing" - "was to prove the low point in the twentiethcentury history of British literary censorship" in terms of the reputation of the legal system. ${ }^{10}$ As publisher of the novel, Jonathan Cape's attempts to control the accusations, initially by appearing to co-operate with the Home Secretary and then moving printing to Paris, were both disastrous, and only served to increase the timidity of other presses. The trial was important because of the degree to which members of the literary establishment were prepared to defend the novel, and also in that it established by precedent a guiding principle that virtually no expert testimony on a book was admissible. ${ }^{11}$ As the Magistrate remarked, "I don't think people are entitled to express what is merely an opinion upon a matter which is for the decision of the court."12 More remarkably still, on appeal the defence was informed that it was neither "appropriate nor practicable" for the bench to read the book in question. ${ }^{13}$ Such developments built upon a legal framework where the motivation of the author, publisher, or bookseller uniquely inadmissible for "in obscenity cases alone, the question of motive was irrelevant to the issue of guilt." ${ }^{4}$ As many commentators have made clear, had such laws been applied universally, "it would have reduced the ranks of English literature to the level of the nursery." 15 Virginia Woolf suggested that to abide by the law in all instances, modern books would have to become "so insipid, so blameless, so full of blank spaces and evasions that we cannot read them." ${ }^{16}$ This near-inescapable web of restriction discouraged publishers both from releasing potentially controversial works, and from defending them upon any complaint. The risk, the expense and the damage to prestige were all the publisher's; as Craig's own publisher, Sir Stanley Unwin phrased it, "the position is by no means easy."17

10 Alan Travis, Bound and Gagged: A Secret History of Obscenity in Britain (London: Profile, 200o), pp. 46, 45 .

11 Diana Souhami has analysed the lack of real engagement with the novel shown by such figures, though many were happy to be associated with its defence. See Diana Souhami, The Trials of Radclyffe Hall (London: Virago, 1999).

12 Craig, Banned Books (see above, n. 2), p. $3^{8}$.

13 Ibid., p. 40.

14 Travis, Bound and Gagged (see above, n. 10), p. 7.

15 Ibid.

16 Virginia Woolf, 'The Censorship of Books,' The Nineteenth Century and After, 105 (1929), 446-7, there 447 .

17 Stanley Unwin, 'Introduction,' in John Hampden, ed., The Book World Today: A New Survey of the Making and Distribution of Books in Britain (London: Allen \& Unwin, 1957), pp. 9-16 (p. 12). 
Arguing strenuously against the logic and moral intentions of the legal framework, Craig demanded reform on the basis that the current law could not, for reasons of practicality amongst many others, be applied universally and fairly. As he pointed out, "a law which is only invoked arbitrarily and spasmodically ceases to be a law in the true sense of the word."18

While Craig advanced various options for reform, his ultimate position in The Banned Books of England and its companion volume, Above All Liberties (1942), was the necessity of "making literature free from all shackles legal, economic and social."19 Indeed, he suggested that this was "essential to the continuance of civilisation as we know it." ${ }^{20}$ Such sonorous, unequivocal demands for freedom are easily assimilated into a wider cultural perception of artists and writers of the period as "culture heroes...champions of free expression and avatars of sexual liberation." ${ }^{21}$ At his most bombastic, Craig sometimes presents the situation as a clear, Manichean struggle between progressive literature and what he came to call with increasing bile the "censor-morons," representatives of "reactionary authoritarianism, fanatical puritanism, official stupidity."22

Celia Marshik suggests in her study-of British Modernism and Censorship (2006), that the late nineteenth and early twentieth centuries were marked by authors who "inscribed themselves in the social text as bold defenders of artistic freedom." ${ }^{23}$ Such a posture could be motivated by a desire to increase the speaker's prestige. As Elisabeth Ladenson points out, "subversion and transgression" of the restrictions of censorship "had become positive values in themselves." ${ }^{24}$ Such a pursuit of prestige clouds any easy conclusions about literary and artistic attitudes to censorship. As John Carey's influential analysis emphasises, while the significance of art was "reckoned to be directly proportionate to its ability to outrage and puzzle the mass," the "truly meritorious in art is seen as the prerogative of a minority." ${ }^{25}$ While Craig's message found a receptive audience, such an attitude to transgression could have been born not of a passion for freedom but from this elitist stance. In one passage in

18 Craig, Banned Books (see above, n. 2), p. 79.

19 Craig, Above All Liberties (see above, n. 7), p. 108.

20 Ibid., p. 109.

21 Loren Glass, 'The Ends of Obscenity,' American Literary History, 21 (2009), 869-76, there 869 .

22 Craig, Banned Books (see above, n. 2), pp. 194-5.

23 Celia Marshik, British Modernism and Censorship (Cambridge: Cambridge up, 2006), p. 5 .

24 Elisabeth Ladenson, Dirt for Art's Sake: Books on Trial from Madame Bovary to Lolita (London: Cornell UP, 2007), p. xx.

25 John Carey, The Intellectuals and the Masses: Pride and Prejudice among the Literary Intelligentsia, 1880-1939 (London: Faber and Faber, 1992), p. 18. 
The Banned Books of England, for instance, Craig laments the practice of protecting books from obscenity prosecutions by high prices, suggesting that "ideas that have been current coin among the well-to-do educated for more than a quarter of a century are unfamiliar to the equally well-educated of the less affluent ranks of society."26 Despite Craig's seemingly unlimited demands for freedom and the myth of modernism's opposition to censorship in all of its forms, clear limits were adopted in the championing of literary freedom. Examining the shape of such limits provides a pattern of categorical distinctions that illuminate the cultural and commercial realities underlying the rhetoric of freedom as championed by Craig and many modernist writers.

\section{"Few People Would Like to See it in the Hands of the General Public"27}

While recognising censorship as an unwelcome and repressive force, many of Craig's fellow writers saw the literary marketplace as infected with one distinguishable commodity that could happily be abandoned to the censor: pornography. E.M. Forster, who would write a foreword for-Banned Books of England, felt confident that pornographic works "are easily detected and classified, for the reason that their aim is not literature, but physical provocativeness." 28 Virginia Woolf, a little more euphemistically, defined this class of writings as those created with the "object of causing pleasure or corruption by means of their indecency."29 Both writers advocated the censorship of such material. This chapter does not seek to define or quantify the material which such figures identified as pornography, though it is worthy of remark that the history of such a trade remains largely unexplored. It is however vital to stress the insistence of many writers on the observable validity of the category of pornography. This is true even of those of the most libertarian views; for example, D.H. Lawrence insisted that he "would censor genuine pornography, rigorously. It would not be very difficult." 30 In all of these cases, what is compelling about the idea of pornography, regardless of its reality, is its power to disrupt calls for literary and artistic freedom.

\footnotetext{
26 Craig, Banned Books (see above, n. 2), p. 168.

27 Ibid., p. 153 .

28 E.M. Forster, 'The Censorship of Books,' The Nineteenth Century and After, 105 (1929), 444-5, there 444 .

29 Woolf, 'Censorship,' (see above, n. 16), there 446.

$30 \quad$ D.H. Lawrence, Pornography and Obscenity (London: Faber and Faber, 1929), p. 12.
} 
Craig was suspicious of the ease with which writers such as Woolf or Forster could define the pornographic. For example, of their idea of it residing in authorial intention, he objects "this is entirely unsatisfactory, for who is to look into the mind of the author?"31 He further concedes that a focus on the effect on the reader "is hopelessly subjective" as "what stimulates one person will not stimulate another." ${ }^{32}$ However, Craig did believe in the objective existence of pornography, and cited one writer as example repeatedly, the Marquis de Sade, whose works he describes simply as "evil." ${ }^{33}$ With Sade he is confident, in terms that recall the most determined anti-vice campaigner, that "to any ordinary mind it is revolting" and that "few people would like to see it in the hands of the general public." ${ }^{34}$ The contrast to his claims for liberty is striking, although he simultaneously concedes that there are discourses in which even such material may have value: "when written by a man of the ability of de Sade this type of pornography has a certain legitimate interest not only to the alienist and the sexological specialist but to the literary man." ${ }^{35}$ Alive to the problematic nature of defining pornography, Craig is attuned to the literary avant-garde of his time and their attempts to erode the distinction between literature and the obscene. For example, Craig champions Ulysses, saying that "the literary importance of the work is beyond all cavil"; as Alison Pease has remarked, Joyce's "appropriations of pornographic tropes and images" served to "shape our understanding of...literature such that its difference from pornography in both function and form has been made less clear."36

In this light, Craig's treatment of Sade seems a reflection of contemporary literary culture, but he is still incongruously unwilling to abandon the idea of pornography as a separate and identifiable category: "if we want free literature we must bear with pornography." 37 The idea of pornography as a recognisable element of the book world seems inescapable and to require no exploration, so that for example John Feather suggests in his landmark history of British publishing that "no account of Victorian publishing is complete without pornography" (he then spares it less than one page). ${ }^{38}$ Its acknowledged existence as something which will not be discussed permits a discussion.

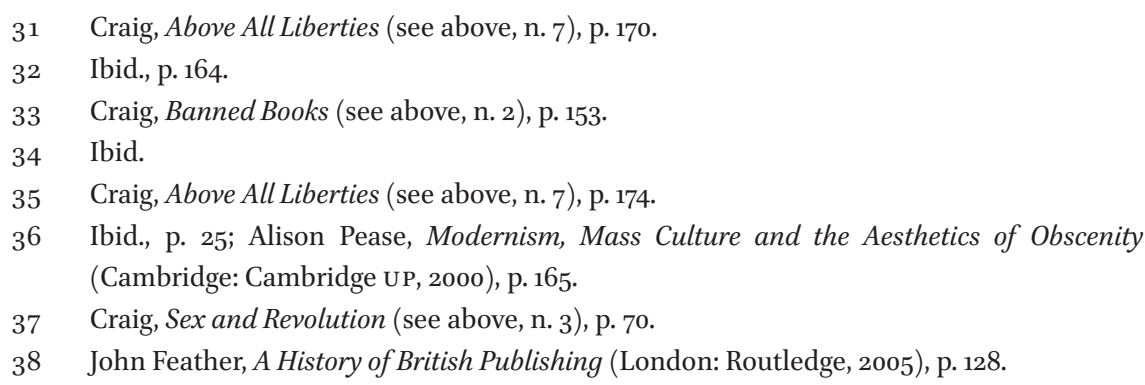


Indeed, it seems at least plausible to suggest that for Craig the idea of pornography was indispensable, even if in practice not one unambiguous example of it could be provided. The structural schema this suggests, with a hierarchy of meaning resting upon a condemned if inexact foundation, has a fascinating analogy with the structuring of the world of books and bookmen in which Craig situated himself and upon which he relied for support and a voice.

\section{The Book World: "Responsible London Publishers," and the Rest}

The book world was a self-consciously constructed sector, as works such as The Book World (1935) and The Book World Today (1957) testify, as do the many biographies and memoirs offered to the public by those from these professions. ${ }^{39}$ As a body, the trade was united against censorship and they sought to bring control of published material back within their own hands. For example, Stanley Unwin speaks of possible legal reforms that would "be accepted by, and secure the wholehearted co-operation of, all responsible publishers," as if firms had special rights and such co-operation were not a matter of legal obligation. ${ }^{40}$ Craig also suggests a system of self-regulation, as "most writers would agree" that "a sense of responsibility is proper" and "the question of proper caution must be left to the writer and the critic." ${ }^{41} \mathrm{He}$ further insists that "I see no reason why the law should attempt to make this responsibility a legal obligation." ${ }^{42}$ Elsewhere he argued that "a man should defer to the judgment of his intellectual peers and of his fellow writers," arguing that "I believe that there is such a thing as literary conscience among us to-day." ${ }^{33}$ The book trade is here presented as a case apart, following a higher discourse. Craig's arguments and metaphors frequently amount to a sleight of hand that seeks to use the censorship debate to sanctify the book trade. For example, he suggested of interminable court proceedings that "so long as we chase the bogey of 'pornography' we cannot be, we cannot expect to be, a free and civilised community." 44 This is

See for example Frank Swinnerton, A London Bookman (London: Martin Secker, 1928); James Milne, Memoirs of a Bookman (London: John Murray, 1936); Joseph Shaylor, Sixty Years a Bookman (London: Selwyn \& Blount, 1923).

40 Unwin, 'Introduction,' to Hampden, ed., Book World Today (see above, n. 17), p. 13.

41 Craig, Banned Books (see above, n. 2), p. 159.

42 Ibid.

43 Alec Craig, 'The Conception of Literary Obscenity and the Freedom of Letters,' in Herman Ould, ed., Freedom of Expression: A Symposium (London: Hutchinson International Authors, 1944), pp. 135-40 (p. 139). 
a powerful, but ultimately vague demand, yet it is followed with the remarkable comparison that such pursuit "is no more consistent with civilisation than witch-hunting, to which it bears a close psychological resemblance." 45 The bold analogy between a process that led directly to death and physical suffering and the restrictions placed upon publishing equates bodies and books, while simultaneously concealing questions of the value of individual texts.

Craig's exclusive "us" in his proclamation of a "literary conscience among us" refers to the community of publishers and authors, but the world of bookmen was not as unified as such phrases suggest. Rather, as Carey argues of the literati, the publishing industry was deeply and energetically stratified in a process that Mary Hammond has called "qualitative categorisation" which applied to both firms and their products. ${ }^{46}$ As Nicola Wilson suggests of fiction but in ways which hold true for all publishing endeavours, "as the audience...became more diverse and stratified, so too did the novel as a form." ${ }^{27}$ One instance of the operative power of such structuring is apparent in response to the perceived censorship of attempts to advertise Craig's first work. Allen and Unwin took out an advertisement for Sex and Revolution in The Listener which was removed without warning before publication, presumably because of the first word of the title. It might be imagined that Unwin would react with the full force of Craig's own arguments of freedoms and civilised discourse. Instead he chose to ask Geoffrey Faber to write on his behalf, and that letter focuses on the financial realities of the literary marketplace. Faber tersely mentions that his firm "advertises a good deal in "The Listener," and suggests that if such decisions became common the magazine would not be "as useful an advertising medium for us as it has been in the past." ${ }^{8}$ While Faber hesitates to delineate the patterns of commerce, he is clearly thinking of both The Listener's need for advertisers, and his own company's need to advertise. His reluctance to admit this openly will be returned to, but his only contribution to the ethical dimension of the incident is to stress that the advertisements he places are for "our serious publications," and that Craig's book is similarly discussing its subject matter "honestly and seriously."49

45 Ibid.

46 Mary Hammond, Reading, Publishing and the Formation of Literary Taste in England, 1880-1914 (Aldershot: Ashgate, 2006), p. 5 .

47 Nicola Wilson, 'Libraries, Reading Patterns, and Censorship,' in The Oxford History of the Novel in English, 12 vols. (Oxford: Oxford U P, 2011-), 4: 36-51 (p. 37).

48 Geoffrey Faber to R.S. Lambert, 7 May 1935. Reading, University of Reading Special Collections (hereafter UoR), Records of George Allen and Unwin, MS 3282, AUC 44/27. Ibid. 
The integrity of Faber and Unwin's firms is stressed in this incident in a united front against an unnamed, lesser contingent of the publishing industry, whose books are presumably not serious and which should not be immune from censorship. "Seriousness" is the marker of that qualitative categorisation, where certain publishers - as perhaps the personifications of "literary conscience" - guarantee the appropriateness of the matter they publish. The terms are at best imprecise, and to speak of seriousness evades all mention of subject in ways that would have been regarded as irrelevant in a British court. Arguably, the real force of Faber's argument, outside of the concealed threat to withdraw advertising revenue, is in an indirect denial that this book belongs to another class of publication, the shadowy presence that Woolf, Forster, Lawrence, and even Craig were happy to see censored. As Lawrence Rainey points out when discussing the stratification of book publishing, each strata was clearly valued, so that literature "gradually acquired a class structure analogous to that of the social world surrounding it." 50 In these terms, Faber tacitly recognises the regrettable existence of a 'lower' class of literature - the pornographic - which might happily be censored, in order to insist that Craig's book does not belong to that underworld.

This is repeated in Stanley Unwin's discussion of the trials of dealing with accusations of obscenity. He describes the police's "almost indiscriminate" seizure of books "in various provincial cities," but stresses that "the seizure of a portion, possibly even of a large portion, of the books was justified." ${ }^{51}$ It is striking that Unwin is willing to abandon swathes of the publishing industry to the hands of policemen whom he admits do not trouble to discriminate. There is only a small amount of material which he insists should be immune, and that is "literary works by responsible London publishers." ${ }^{2}$ Responsible London publishers, presumably of serious books, must remain above restrictions, and the adherence to law or reference to definitions of obscenity are not to be discussed. Unwin stresses that "the position of reputable...publishers was intolerable" without seeking to define how such firms are to be identified. ${ }^{53}$ These categorical distinctions have very little to do with "fighting a grim fight against obscurantism, oppression and persecution." ${ }^{54}$ Most pressingly this is a matter of

50 Lawrence Rainey, Institutions of Modernism: Literary Elites and Public Culture (New Haven: Yale, 1998), p. 2.

51 Stanley Unwin, The Truth about a Publisher: An Autobiographical Record (London: Allen \& Unwin, 1960), p. 385 .

52 Ibid.

53 Ibid., p. 386.

54 Craig, Sex and Revolution (see above, n. 3), p. 75 . 
corporate status, but even geographical location becomes a criterion by which such things should be judged. Unwin goes on to suggest that in those provincial cities, "where the offending books bore the imprint of a London publisher the case should be referred" to the Home Office rather than leaving it to local police. ${ }^{55}$ Clearly, some firms are their own guarantee of the probity of their work, and for those not lucky enough to claim a London address, the best defence was to reinforce the existence of the disreputable, irresponsible, pornographic press the police sought, in order to distance themselves from it. As Craig did not name one unambiguously pornographic work, so Unwin and Faber do not need to, for by supporting the idea of the existence of such reprehensible books, they emphasise their firms' (and their products') elevation above them.

\section{"Not be Harnessed to Material Ends"56}

It is not merely a matter of prestige which delineates the divisions of publishing, but also, and perhaps most importantly, the pursuit of profit. It has already been seen that Geoffrey Faber was unwilling to admit such a dimension to his business (while covertly pressing it), but this is true in similarly submerged terms across the industry. There is a powerful image in publishing circles of the responsible bookman: literary-minded and working in the service of culture. The commercial realities of the industry, and even those who purchased the books and financed it, are bizarrely absent from many discussions of publishing and censorship. For example, F.D. Sanders, surveying the structure of the book trade in 1957, could remark of the role of the book buying public that while it was "most important," it was "sometimes overlooked." 57 An appetite for books is often simply assumed in such discourse, with the resulting elision of any sense of the book as a commercial product as it becomes a needed object with its own intrinsic rights to movement and freedom from suffering. In his introduction to Hampden's second edited collection of essays, Craig's publisher Stanley Unwin stressed this idea of the quasi-sacred status of books, suggesting with abhorrence that the governmental "ill-treatment of books is... due to treating them as "just another commodity." 58

\footnotetext{
55 Unwin, Truth about a Publisher (see above, n. 51), p. 386.

56 Craig, Sex and Revolution (see above, n. 3), p. 75.

57 F.D. Sanders, 'The structure of the book trade,' in John Hampden, ed., The Book World Today: A New Survey of the Making and Distribution of Books in Britain (London: Allen \& Unwin, 1957), pp. 38-50 (p. 38).

$5^{8}$ Unwin, 'Introduction,' to Hampden, ed., Book World Today (see above, n. 17), p. 10.
} 
In his study of Popular keading and publishing in Britain 1914-1950 (1992), Joseph McAleer has argued that after 1870, British publishing divided into two schools: one the "improving or optimistic school" and the other "wholly commercial and entrepreneurial." 59 This tension between improving and commercial can profitably be laid alongside the shifting definitions of the pornographic and the reputable. Both registers of meaning serve to stratify the publishing industry, usually to the benefit of the bookman who is speaking. A rather fraught ambivalence to profit can be seen powering the discussion of Craig's own work with his publisher, with both parties placing Craig's writing unquestionably on the side of the "improving or optimistic school." While interest in profit is repeatedly denied, in the process author and publisher write of little else. In his letter accompanying the manuscript of Above All Liberties, for instance, Craig suggested euphemistically that a little advertising may "give the book a good send off." ${ }^{\circ}$ Unwin at once reminded Craig that "we have lost money on one of your books, and only just got back out-of-pocket expenses on the other," but that they would still "like to be connected with the publication." ${ }^{61}$ He cited the cost of paper as a reason to delay, but Craig shamed him by suggesting that "motives on both sides are perhaps not strictly commercial." 62 Unwin then magnanimously insisted that while "there is no commercial inducement," he would take the book on. ${ }^{63}$ It is worth being clear here that Unwin was an astute and successful businessman who only consented once Craig waived his royalties, and that Craig's considerable correspondence with other staff at the publishing house was entirely concerned with calculations of monies due for his other titles.

What these letters reveal is a shared need to assert an elevation above the commercial imperative, a stratification comparable to the loud denial of being anything but serious and reputable. The pornographic and the commercial both represent an unpalatable, if unclear, category against which other works can be defined and defended. Indeed, there is subtextual linkage between the two categories in Craig's works. Whenever he mentions pornography it is shadowed by a suggestion of the commercial, as for example when he speaks of the "vast trade" in London pornography ${ }^{64}$ Similarly, he is clear what the motivation of the writer of pornography might be, a "disreputable scribbler who seeks to

59 Joseph McAleer, Popular Reading and Publishing in Britain 1914-1950 (Oxford: Oxford UP, 1992), p. 12.

6o Craig to Unwin, 31 March 1941. MS 3282 (see above, n. 48), AUC 109/4.

61 Unwin to Craig, 14 May 1941. Ibid.

62 Craig to Unwin, 17 May 1941. Ibid.

63 Unwin to Craig, 23 May 1941. Ibid.

64 Craig, Banned Books (see above, n. 2), p. 21. 
turn a dishonest penny." 65 He also describes pornographic works as "trundled openly abroad and secretly at home," where the unusual verb calls to mind the street seller intent on a profit. ${ }^{66}$ Lastly, his most extravagant hope for a society run on "modernist" thinking was that love "will not be harnessed to material ends." ${ }^{7}$ In other words, love and sex, like literature, are sullied by contact with the market place, which introduces a lower-value discourse.

Such linkage was common in rhetorical and ideological terms amongst Craig's contemporaries. For example, profitability is an inescapable marginal presence in Havelock Ellis's statements on obscenity. In More Essays of Love and Virtue (1931), Ellis states that "it is law alone which makes pornography both attractive and profitable." ${ }^{8}$ He accuses the Home Secretary and his civil servants of being "directly responsible for the creation of the 'filth' which supplies the demand." 69 Profit is here clearly aligned to filth: pornography is fundamentally profitable. In both cases, the idea is present but not quite openly stated, as if to do so would itself be sullying. Every aspect of the production of texts was tied to these polarities of the commercial and the pornographic on the one side, and the high-minded and literary on the other. Virginia Woolf's 1929 essay on censorship, while inflected with an irony characteristic of the author, makes clear that an overriding interest in commercial matters could even transform the nature of the material sold into pornography. Woolf insists that the law must:

distinguish between books that are written or sold for pornographic purposes and books whose obscenity is an incidental part of them - between Aristotle's works as they are sold in the rubber goods shops, that is to say, and Aristotle's works as they are sold in the shops of Messrs. Hatchards and Bumpus. ${ }^{70}$

The "rubber goods shop" is the counterpart to the disreputable publisher, while in the distinguished space of Hatchards bookshop (supplied by firms like Allen and Unwin's), essentially the same goods are absolved of commercial interest and pornographic intent. The denial of being pornographers and the denial of

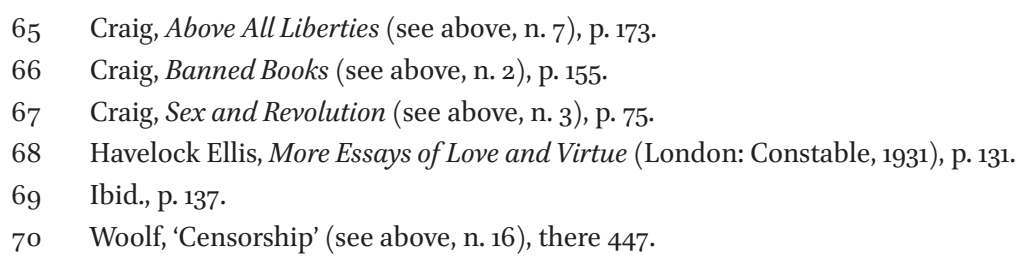


commercialism are mutually supporting. Audience and the means of distribution are all.

That firms were aware of this distinction as an elaborate but not inflexible pose is evident in another of Craig's relations with Allen and Unwin. Amongst the firm's records are readers' reports for two works by Craig which were ultimately not published, and that are now seemingly lost. One was a short account of nudism, of which Craig was told that its length and subject were both awkward. However, the publisher's reader had qualified these opinions with a suggestion for improving its prospects. He suggested that the work "would be difficult to sell in wartime - unless, of course, it was photographically illustrated with a few of the nudes...wherein there is no retouching or concealing posture. If there were eight such plates in this in this $5^{0-} \mathrm{pp}$. book, it might sell."71 "Retouching" was the process by which all suggestion of genitalia or pubic hair was removed from such images, and even the nudist press "continue to observe a tradition of careful posing and...retouching." ${ }^{2}$ While this suggestion was not adopted, it was seriously suggested by one of the publisher's most regular readers, and annotations on the original show that it was considered at the publishing house. While maintaining the discourse of the reputable and serious-minded, Allen and Unwin at least proposed the publication of radically explicit photographs in the interest of increased profits.

There is a powerful drive within the publishing industry to structure itself through a heavily freighted avoidance of purely commercial interests. Clearly this drive exists outside of sexual material, but when it collides with issues such as censorship the two rapidly synthesise. There are deeply abiding contradictions where competing drives circle, if neither eradicating nor cultural unease; pornography is vilified, yet its appeal is universally recognised, and publishers pursue profits they repudiate. What is concealed here is that, as Stallybrass and White put it, "disgust always bears the imprint of desire."73 The recognition of the "striking ambivalence to the representation of the lower strata (of the body, of literature, of society, of place) in which they are both reviled and desired" grants some understanding of the inescapable contradictions inherent in a culture's responses to the drive to censor. ${ }^{74}$ This contradictory flight away from a force which yet holds the speaker in its thrall results, for

71 Reader's report on Craig's Nudism, 10 September 1940. MS 3282 (see above, n. 48), AUR R $9 / 1 / 18$.

72 Craig, Sex and Revolution (see above, n. 3), p. 100.

73 Peter Stallybrass and Allon White, Politics and Poetics of Transgression (New York: Cornell UP, 1986), p. 191. 
Stallybrass and White, in a series of ritualistic, seemingly paradoxical behaviours. Craig's last writings and the fate of his own book collection are illuminated by examination of this elaborate, performative vacillation.

\section{Coda}

As early as 1957, Craig had considered the donation of his own collection of censored and theoretical works to the University of London Library (now Senate House Library, University of London). However, he still feared its absolute suppression, as he confided to the American sexologist Gershon Legman: "I am thinking of leaving my library to the University of London - if they would take it and not bury it."75 Legman recommended the library as a "rational and wideawake outfit," and so a safe home. ${ }^{76}$ Ultimately, Craig's library, amounting to something like 3,000 volumes, was gifted to Camden Council, with the understanding that they were free to distribute them as they saw fit. As the Council committee warmly thanks Craig's widow in its minutes, it adds that "that part of the collection which, because of its rarity and subject, would have to be used in the controlled academic library situation" had been donated to Senate House Library. ${ }^{77}$ In "rarity and subject," the committee is handing down a euphemistic judgment, and there is a suspicion that this transgressive residue was eagerly dispatched. However, despite selecting material and adding it to Senate House's collections, the Director's letter, in response to Craig's widow's hope that the books "will be of great use to those interested," bears a bold and final annotation which she would not have seen: "16th floor, locked."78 While limited access was granted to researchers who were already aware of them, the works were banished to a high floor of the tower the library now occupies, uncatalogued, and essentially inaccessible. The collection was enclosed in a locking wire cage, as if it were a hazardous beast.

There is a painful and inescapable irony in Craig's being effectively, if covertly, censored in the library. It is as if all of Craig's assembled arguments have been summarily silenced by a sweeping decision from a librarian. This seems all

75 Craig to Gershon Legman, 13 March 1957. London, Senate House Library, Alec Craig Archive, MS 1091: box 1/file 2 .

76 Gershon Legman to Craig, 1 April 1957 (see above, n. 75).

77 London Borough of Camden Local Studies and Archive Centre, Libraries and Arts SubCommittee Minutes, Minutes of meeting held 29 January 1974.

78 D.T. Richnell to Kathleen Craig, 12 October 1973. London, Senate House Library, University of London Archive, UoL/UL/4/18/15. 
the more poignant in that Craig had stressed in his 1962 revision of his earlier work that the "learned and scholarly libraries can be trusted to transact their affairs in the highest interests of science, literature and art," where "highest" makes clear the institutional differentiation away from the lower, problematic discourses. ${ }^{79}$ Craig had envisaged the academic library as an environment where anxieties over repression were misplaced, and was even happy to countenance something approaching censorship, conceding that "libraries are bound to exercise caution over the issue or circulation of controversial items," fearing "the attentions of the sexual maniac." 80 The library becomes in such a reading a privileged location, perhaps because of its place outside of the literary marketplace with its ambivalent commercial drives. Extraordinarily, when Craig discusses leaving his collection of transgressive works to such a library, it is even safe to lapse back into vocabulary he had previously ridiculed as "hopelessly subjective," saying that "I want to donate or bequeath my erotic books to some library." 1

In the decision to effectively conceal Craig's library, the floors of Senate House Library's tower become an inverted metaphor for society's attitude to the potentially erotic, with the transgressive "low" banished "high." This is a performative act of what Stallybrass and White would term "symbolic reterritorialization," marked by the unacknowledged certainty that such an attempt is unsound. ${ }^{82}$ The ostentatious banishment of the Craig collection also entails careful preservation. The library is enacting an "imperative to reject and eliminate the debasing "low'" which simultaneously "conflicts powerfully and unpredictably with a desire for this Other." 83 This recalls Craig's own seeming vacillation before De Sade, as well as Stanley Unwin's pursuit of, and dismissal of, profit. Society, and even reformers like Craig, demanded the reassuring presence of a symbolically locked, hidden floor holding abjected contents which would be released only in appropriate circumstances; great libraries like Senate House supplied it but also perpetuated it as reflections of the cultures they served. The word "abjected" is used advisedly, for Kristeva's description of the power of the overwhelming yet pathologically rejected abject speaks to that carefully retained but elaborately restricted material on the sixteenth floor: "one does not know it, one does not desire it, one joys in it [on en jouit]... victims of the abject are its fascinated victims." 84 Such collections are created,

\footnotetext{
79 Craig, Banned Books (see above, n. 2), p. 205.

8 Ibid., p. 206.

81 Craig to Gershon Legman, 16 September 1964 (see above, n. 75), emphasis added.

82 Stallybrass and White, Politics (see above, n. 73), p. 192.

83 Ibid., p. 4.

84 Julia Kristeva, Powers of Horror: An Essay on Abjection, trans. Leon S. Roudiez (New York: Columbia UP, 1982), p. 9.
} 
and elaborately set aside, in a library firmly outside of the clashing commercial and intellectual imperatives which mark the literary marketplace; it is in this comparative quiet that the library can accede to pass judgment, and its pronouncement is an ostentatious indecision.

When Craig wryly remarked that "although the wisdom of trying to protect fools from books is open to dispute the necessity of protecting books from fools is not," he was thinking of the library's duty to preserve its stock from defacement and other purely physical attack. ${ }^{85}$ However, it is clear that certain types of transgressive content can drive librarians, publishers and other bookmen - including Craig - to make confused and perhaps foolish judgments of categorisation from which books may need more abstract protection. Where the vision of Alec Craig is most to be praised is in his realisation of the futility of attempting to surmount such societal ambiguity and hypocrisy; in concluding his last published work, Craig could intone with striking pragmatism that "we are all tempted to be both readers of erotic books and censors of sexual literature," throwing the confusion back on to each and every reader. ${ }^{86}$ This is a bold and redemptive conclusion to his struggle, an acceptance that he cannot, however many times he rewrites his study, reach a logical conclusion within the terms of the debate as it has been handed to him. Surveying his subject after forty years, he bequeaths the cultural confusion of obscenity and of commercialism to a generation more attuned to the abandonment of sweeping metanarratives.

85 Craig, Banned Books (see above, n, 2), p. 206.

86 Ibid., p. 218. 
